\title{
Exploring Soto Zen in Peru Investigando Soto Zen em Peru
}

\section{Germán McKenzie*}

Abstract: Soto Zen has grown in importance in Peru since 2005, a phenomenon that has not yet been well studied. To analyze such a process, this research uses the "processive modes" theory as developed by M. Baumann and the Rational Choice Theory as applied to religion by R. Stark and R. Finke. It draws upon qualitative data collected through semistructured interviews and written questionnaires conducted in two stages, the first one between 2007 and 2009, and the second one in 2013, as well as through participant observation. This study concludes that after deploying important organizational, institutional, communicational and financial resources, today's Soto Zen presence in Peru can be characterized by the drive to adapt its tradition to Peruvians on the one hand, and maintaining a connection to its roots on the other. As a consequence of these two realities, the Soto Zen community is facing tensions between ordained leadership and lay members. These may jeopardize the strategic position the community has within the Peruvian religious marketplace.

Keywords: Zen Buddhism, Peru, transplantation, trans-national religion

Resumo: Embora a importância de Soto Zen em Peru tenha crescido, desde 2005, o fenômeno ainda não foi suficientemente estudado. Para avançar com a anlise, este artigo apropria-se da teoria de "modos progressivos" desenvolvido por M. Baumann e da teoria de R. Stark e R.Finke. $O$ texto refere-se a dados qualitativos levantados por entrevistas semiestruturados, por questionários preenchidos entre 2007 e 2009 e em 2013, respectivamente, e por observaçóes participantes. $\mathrm{O}$ estudo demonstra que devido a enraizamento de importantes recursos no sentido organizacional e institucional bem como em termos de comunicação e do financiamento, a atual presença do Soto Zen em Peru pode ser melhor caracterizada como esforços de adaptar sua tradição aos peruanos, por um lado, e, por outro lado, de manter-se fiel as suas raízes. Consequentemente, a comunidade Soto Zen está enfrentando tensóes entre a liderança ordenada e os praticantes leigos. Tratase de algo que pode pôr em risco a posição estratégica da comunidade no âmbito do mercado religioso peruano.

Palavras-chave: Budismo Zen; Peru; transplantação; religiáo transnacional

\footnotetext{
*Assistant Professor St Mark's \& Corpus Christi Colleger, University of British Columbia, gfmckenzie@gmail.com
} 


\section{Introduction}

Studies on the presence of Buddhism in South America, and of Soto Zen in particular, are in its beginnings ${ }^{1}$, with the exception of Brazil ${ }^{2}$ and Argentina ${ }^{3}$. This article is a preliminary approach to a topic not well covered in the literature and analyzes how Soto Zen Buddhism is being transplanted into Peru. Soto Zen's life in Peru began with the large Japanese immigration of 1899-1936. After some time, most of this population converted to Catholicism. In 2005, there was a new start for Soto Zen in Peru with the move to Lima of Roshi Jisen Oshiro, a Soto Zen nun who started her work reaching out to people interested in Zen regardless of their background. Her mission depends administratively on the Busshinji Temple in Sao Paulo, Brazil. I intend to study this second stage of Soto Zen's history in the country.

\section{Theoretical Framework}

This study makes use of the "processive modes" theory as developed by M. Baumann, which helps to study the ways in which the transplantation of a given religious tradition, as embodied by a group, occurs amidst a host culture embodied in a particular society. The analysis is formulated in terms of the new coming tradition, Soto Zen in this case. These processive modes are defined as ways of adaptation, and can be applied to any religious tradition that enters into a new socio-cultural context that is different from where the religious tradition already "lives." What triggers the whole process may or may not be a migration phenomenon. Baumann distinguishes five modes of transplantation which are not necessarily successive, nor must all be present in each concrete experience of transplantation: contact, confrontation and conflict, ambiguity and adaptation, re-orientation, and innovative self-development. ${ }^{4}$ In what follows, each mode is defined where appropriate. Additionally, my analysis makes use of Rational Choice Theory as applied to religion by Stark and Finke. ${ }^{5}$ I will use this approach transversally through the different processive modes, specifically when their focus on religious competition and their views on the rise of "new religions" in a given "religious economy" prove to be useful for my analysis.

\footnotetext{
${ }^{1}$ F. Usarski, Buddhism in South America.

${ }^{2}$ C. Rocha, Zen Buddhism in Brazil; C. Rocha, Being a Zen Buddhist Brazilian; C. Rocha, Zen in Brazil; F. Usarski, Buddhism in Brazil and Its Impact on the Larger Brazilian Society.

${ }^{3}$ C. E. Carini, Budismo global, budismo local; C. E. Catón Eduardo: Ritual y poder en los centros budistas zen argentinos; C. E. Carini, Las nuevas tierras de Buda.

${ }^{4} \mathrm{M}$. Baumann, The transplantation of Buddhism to Germany.

${ }^{5}$ R. Stark; R. Finke, Acts of Faith.
} 
Stark and Finke's theory affirms that religious change at the organizational level is explained by changes in "religious supply": religious organizations compete among themselves while trying to cater to their potential "clients." Their ability to do so depends on the way they target specific profiles of individuals ("niches") and on what they offer to them, who then decide between the available religious options they see according to a cost/benefit analysis. The religious tradition (if any) in which each person has been raised is considered to be his/her "religious capital." This concept refers to the degree of cultural mastery possessed by the individual with regards to their religious tradition and to the emotional attachment to this tradition. As per the "demand" side (i.e., religious interest on the part of individuals), it is seen as reflecting personal preferences in the context of a spiritual journey.

My claim is that Soto Zen's presence in Peru today can be described by the drive for adapting the tradition for Peruvians on the one hand, and keeping faithful to its roots on the other. In this context, the community is facing tensions between ordained leadership and lay members as to the goal of Soto Zen practice and how to acculturate it within the Peruvian context. These may seriously jeopardize the strategic position the community has achieved within the Peruvian religious marketplace.

\section{Methodology}

Qualitative data was gathered through semi-structured interviews and written questionnaires in two stages, the first one between 2007 and 2009, and the second one in 2013. I obtained answers from 3 interviewees (out of a universe of 26 individuals) in the first stage and from 12 respondents (out of a universe of 35 people) in the second. Taking into account that the core group of Soto Zen practitioners includes at the present about 30 people, according to convergent accounts by the interviewees, the 15 interviewees correspond to $50 \%$ of the studied population, which makes them significant for a case study. The fact that I was able to interview the persons who lead the Soto Zen presence in Peru also strengthens the significance of the results of this research. Furthermore, I carried out participant observation in ceremonies in the temples during the above mentioned time intervals. I have also carried on a continuous follow-up of the life of the Soto Zen Community in Peru through their official website, its blog, and its Facebook account, as well as their apparitions in Peruvian media, during the years the research took place. The study is also based on a wider set of interviews I did between 2007 and 2013 in order to map Buddhism in Peru.

When respondents are cited, their answers have been translated from Spanish by the author. When appropriate, identity changes have been done in order to protect confidentiality. 


\section{Buddhism in Peru}

Buddhists in Peru constitute a small minority. The last census carried out by $\mathrm{INEI}^{6}$, the government's body in charge of national statistics, includes Buddhist practitioners under the category of "other religions," a group that represented no more than $3.3 \%$ of the population in 2007. On their part, Barrett, Kurian and Johnson ${ }^{7}$ state that Buddhist adherents in 2000 numbered about 57,000, which represented $0.2 \%$ of the country's population, and predict that by 2025 there will be about 100,000, constituting $0.3 \%$ of all Peruvians.

These last figures on Buddhist affiliation might be too high, as I will show next.

Table 1. Number of Buddhist Groups \& Lineages by Location in Peru

\begin{tabular}{|c|c|c|}
\hline Location & Groups & Tradition \& Lineage \\
\hline \multirow[t]{3}{*}{ Arequipa } & 1 & Tibetan \\
\hline & 1 & Vajrayana, Sakya School \\
\hline & 1 & Nichiren Daishonin, Sokka Gakkai \\
\hline Cañete & 1 & Soto Zen \\
\hline \multirow[t]{4}{*}{ Cuzco } & 3 & Tibetan \\
\hline & 1 & Vajrayana, Sakya School \\
\hline & 1 & Soto Zen \\
\hline & 1 & Nichiren Daishonin, Sokka Gakkai \\
\hline Iquitos & 1 & Tibetan \\
\hline \multirow[t]{9}{*}{ Lima } & 1 & Pure Land \\
\hline & 1 & Theravada \\
\hline & 10 & Tibetan \\
\hline & 1 & Vajrayana, Sakya School \\
\hline & 1 & Son, Vipassana Meditation, SN Goenkaji* \\
\hline & 1 & $\begin{array}{l}\text { Zen, White Plum (Rinzai Zen \& Soto } \\
\text { Zen)* }\end{array}$ \\
\hline & 1 & Chen, Non-Sectarian \\
\hline & 2 & Soto Zen** \\
\hline & 1 & Nichiren Daishonin, Sokka Gakkai \\
\hline Piura & 1 & Tibetan \\
\hline $\begin{array}{l}\text { Chimbote, Chincha, Huancayo, Huacho, } \\
\text { Huaral, Ica, La Oroya, Tacna, Trujillo, Tumbes }\end{array}$ & 10 & Nichiren Daishonin, Sokka Gakkai \\
\hline Total & 41 & \\
\hline
\end{tabular}

\footnotetext{
${ }^{6}$ Instituto Nacional de Estadística e Informática - INEI, Perfil sociodemográfico del Perú, p.17. M. Marzal, Categorías y números en la religión del Perú hoy Marzal, pp. 23-34.

${ }^{7}$ D. B. Barrett; G. T. Kurian; T. M. Johnson, World Christian Encyclopedia, p. 590.
} 
Table 1 describes the number of Buddhist groups and lineages by location in the country. If each of these 41 groups includes, as my field research showed, an average of 50 people, the total of Buddhist practitioners would be 2,050 for year 2013. If one assumes Sokka Gakkai's (unconfirmed) figures of membership, which they say to be 50,000 , then the total number of Buddhists in 2013 sits closer to 51,440. Among such Buddhist groups just three belong to the Chen/Son/Zen tradition. Under the same assumptions stated above, Soto Zen practitioners represent no more than 200 people, out of which my field research finds a core group of around 30 persons. They do not regularly interact with the other Buddhist groups and participation in general Buddhist events (usually conferences by some visiting monk) is not encouraged. However small, my research shows that, along with Sokka Gakkai, this community has the best organizational, institutional, communicational and financial resources of all Buddhist groups in the country.

\section{Soto Zen in Contact Mode}

The "contact mode" consists of the arrival of the foreign religious tradition in a host culture. New teachings may be transferred by individuals and groups or impersonally, by texts and scriptures. There is a missionary drive to propagate its religious convictions and give evidence to support them. Translations of important scriptures are undertaken and missionary activity begins.

\section{First Contact: Fostering a Subculture}

As mentioned, Soto Zen Buddhism first arrived in Peru between 1899 and 1923 due to a large Japanese migration ${ }^{8}$. The initial group of immigrants consisted of approximately 26,000 people ${ }^{9}$ who had the intention of improving their economic condition through labor work in order to return to Japan. Most failed to achieve this goal due to the outbreak of World War II, as well as their inability to raise the funds necessary to return home.

Initially, the religious life of these immigrants, the majority of whom were peasants, was centered on a syncretism of Shinto and Zen Buddhism. In their minds, these traditions were not mutually exclusive. With regard to their religion, they generally performed the periodical Buddhist rites and prayers for their ancestors, as well as funerary rites ${ }^{10}$ with a heavily traditional spirit lacking an awareness for the principles

\footnotetext{
${ }^{8}$ I. Lausent-Herrera, Pasado y presente de la comunidad japonesa en el Perú.

${ }^{9}$ M. Fukumoto, Hacia un nuevo sol. Japoneses y sus descendientes en el Perú.

${ }^{10}$ Ibid., A. Morimoto, La religión entre los Nikkei del Perú.
} 
that animated them. ${ }^{11}$ During the first sixty years there were Soto Zen priests from Japan helping the community. Unfortunately, the genesis of WWII brought an interruption to the support received from Japan. This facilitated its decay and there have been no active Soto Zen monks in Peru since $1992^{12}$.

Consequently, as time passed the religious affiliation of the Japanese-Peruvian community changed radically, and became increasingly Catholic. The reasons for this were several: an interest for responding to experienced religious needs, a desire to integrate in Peruvian mainstream culture, and the need of a Catholic certificate of baptism for registering children into schools. ${ }^{13}$ This was also facilitated by the fact that the Catholic Church dedicated priests to outreach the Japanese-Peruvian community, and that more than $80 \%$ of the latter moved to the cities, where they were more easily converted" ${ }^{14}$. The "Nikkei Census" of 1989 showed that, for a total of about 51,000 members of the Japanese-Peruvian community, 92.4\% declared themselves Catholics, $2.9 \%$ Buddhists (that is, about 1,444 persons), $0.2 \%$ Shinto, $0.8 \%$ Evangelical, and $0.1 \%$ Protestant. ${ }^{15}$ In spite of this movement towards assimilation into Peruvian society, endemic racism and post-WWII mistrust prevalent in the latter would mean the process would occur just slowly ${ }^{16}$, which implied that the Japanese-Peruvian community created and nurtured for a long time their own social and cultural associations, as well as schools and charities, in order to provide support and opportunities to its members.

In light of what has been mentioned above, Soto Zen is still familiar to many thirdgeneration Japanese-Peruvians, particularly in some of its rites, and is still part of their religious background even though the allegiance of the majority of them would be with Catholicism. Rational Choice Theory as applied to religion, shows that in making religious choices, most people will attempt to preserve as much of their religious capital as much as possible, and resist religious choices of wholly unknown religious traditions. ${ }^{17}$ Therefore, it can be argued that to Japanese-Peruvians Soto Zen is much more intelligible than any non-Christian non-Zen religious tradition and because of that, it is part of their religious capital in a broad sense. This makes them an interesting audience for the expansion of the Soto Zen community in the country.

\footnotetext{
${ }^{11}$ J. Tokeshi; M. Fukumoto, Integración de los Nikkei a la nacionalidad peruana, p. 264.

${ }^{12}$ J. Oshiro, Zen Sotoshu, pp. 32-33.

${ }^{13}$ I. Lausent-Herrera, Pasado y presente de la comunidad japonesa en el Perú

${ }^{14} \mathrm{M}$. Fukumoto, Hacia un nuevo sol. Japoneses y sus descendientes en el Perú, pp. $495 \mathrm{ff}$.

${ }^{15}$ A. Morimoto, Los Japoneses y sus descendientes en el Perú, pp. 167-173.

${ }^{16}$ L. Lausent-Herrera, Pasado y presente de la comunidad japonesa en el Perú.

${ }^{17}$ R. Stark; R. Finke, Acts of Faith, pp.118-125.
} 


\section{Contemporary Contact}

Currently, the community is led by Roshi Oshiro. She moved to Lima in 2005 to serve Soto Zen practitioners in Peru and in 2008, she was appointed as head priest of Jionji Temple and missionary for the country by the Soto Zen Headquarters in Japan. During the same year, she opened the Nambeizan Zuihoji Temple, in Lima. Roshi Oshiro, an Argentinean ${ }^{18}$, was ordained in 1998 at the Zuioji Monastery (Ehime), a monastery for foreigners in Japan. She has subsequently been appointed to several positions within Soto Zen in Brazil, Japan and Argentina. In April 2005 she was named Soto Zen missionary for South America ${ }^{19}$.

Soto Zen's presence in South America responds to a broad outreach strategy officially sponsored by its leaders. ${ }^{20}$ Bussinji Temple, in Sao Paulo, Brazil, is the headquarters of the Regional Office for South America, from where missionary work is coordinated. The Peruvian Soto Zen community has benefited from the support of Zen monks visiting from Brazil, and from the interest of local people of non-Japanese background. A group composed by the latter was called Zen Friends (Amigos del Zen), and was born in 1997 from the desire to practice zazen meditation. In October 2002, there was a first meeting with Roshi Miyoshi, one of Soto Zen's South American leaders, which provided this informal group with a Soto Zen identity ${ }^{21}$. Since then, this group of Zen Friends has become Soto Zen's core group in Peru.

The arrival of the Roshi Oshiro had a large impact on the instruction and practice of Soto Zen Buddhism, thus forming the identity of the community. It is composed of about 30 individuals, all of them Peruvians. The majority have a Catholic background, are not of Japanese descent, and are interested in meditation ${ }^{22}$. Interviewees also agreed that the majority of practitioners are professionals with graduate and post-graduate degrees, which falls in line with data about Soto Zen transplantation in other non-Asian countries. They also report there are just one or two Peruvian practitioners of Japanese background who belong to the group, and that eventually a few foreigners will join. The first Peruvian-born Soto Zen novices ever-ordained were from this group: Sengen Castilla (novice since 2007) and Tenkai Sanchez (in 2013). Their commitment has been very encouraging for their fellow practitioners. ${ }^{23}$ Besides them, Roshi Oshiro has

\footnotetext{
${ }^{18}$ Peru Shimpo, Templo Jionji fue el sosten espiritual para los inmigrantes japoneses

${ }^{19}$ Comunidad Zen Sotoshu; J.Oshiro, Zen Sotoshu, pp.42-43.

${ }^{20}$ K. Miyoshi, One Hundred Years of Teaching Activity in South America.

${ }^{21}$ N. Castilla, Grupo Amigos del Budismo Zen in Lima.

${ }^{22}$ Z. García, Sesshin in Peru

${ }^{23}$ J.Oshiro, Zen Sotoshu, p. 42.
} 
formally accepted (jukai) about 20 lay persons into Zen Buddhism who expressed a commitment to take the Three Refuges and vowing to keep precepts.

In 2003, the Soto Zen community celebrated a historic mile stone: the $110^{\text {th }}$ anniversary of its presence in Peru through the founding of the Jionji Temple, in Cañete. ${ }^{24}$ The celebration was marked by the renovation of the temple. Additionally, an intense set of celebratory events was also planned in cooperation with the JapanesePeruvian Association (Asociacion Peruano-Japonesa), which is the most important representative organization of the Nikkei community. ${ }^{25}$ These events were covered by some of the most important media outlets for the Japanese-Peruvian community ${ }^{26}$, and for Peruvian society as a whole. ${ }^{27}$ Commemorations also included the publication of a book on Soto Zen in South America. ${ }^{28}$

\section{Variegated Means and Internal Tensions}

Soto Zen makes use of a variety of contact modes in Peru, depending on its target audiences. These include the Japanese immigrant community whose members lived Buddhism as part of their family tradition, or people in general who have at some point acquired the status of practitioner or seeker of Buddhism.

In regards to the first kind of audience, the Soto Zen community is encouraging Peruvians of Japanese background to keep some Buddhist religious practices as a way to maintain cultural roots and thus use them as a stable source of identity. This relationship also ensures support from the well-established organizations of the Japanese-Peruvian community.

In regards to the second type of audience mentioned above, at the present time contact efforts are focused in urban settings, and outreach activities usually target educated middle and upper middle-class individuals, regardless of their religious backgrounds. This is similar to what has occurred in Brazil. ${ }^{29}$ The main actors in this process are the Soto Zen nun in Lima, the newly-ordained novices, as well as the "core group."

An important aspect of this strategy has been the foundation of the above mentioned Nambeizan Zuihoji Temple in Lima. With the building of the Temple,

\footnotetext{
${ }^{24}$ See the Facebook account for the celebrations: https://www.facebook.com/ZenAmericaDelSur (accessed 28 November 2013).

${ }^{25}$ See the website created for the celebration: http://www.zenamericadelsur.org/\#!solutions/ch6q (accessed 28 November 2013).

${ }^{26}$ Peru Shimpo, Templo Jionji fue el sosten espiritual para los inmigrantes japoneses.

${ }^{27}$ El Comercio, El templo Zen mas antiguo de Sudamerica esta en Cañete.

${ }^{28}$ J. Oshiro, Zen Sotoshu.

${ }^{29}$ C. Rocha, Being a Zen Buddhist Brazilian, pp.145-149; C. Rocha, Zen in Brazil.
} 
and though the contact with and support from the "core group," a whole new dynamic of contact has taken place. There are lectures aimed at introducing the general public to Zen on a weekly basis. Zazen sessions for members of the core group occur early every morning, with an average of 6 participants, and there are zazen sessions open to the public in Reducto Park (Parque Reducto) every weekday. The temple also hosts ikebana (flower arrangement) and baika (hymn singing) classes. Roshi Oshiro gives teisho (doctrinal) conferences during the sesshin (meditation retreat) sessions, as well as formal conferences twice a year. There is a whole set of liturgical ceremonies offered all year long. Occasionally, celebrations for a newborn, marriages and funerals also take place. Some of these activities are also carried on at the Jionji Temple, in Cañete, and in Cuzco.

This same missionary logic is found in the work being done to translate some sutras for ceremonies and meditation into Spanish - which have been published recently-, and in the commitment to deliver conferences at universities. In a similar vein, one should mention diverse means of communication such as a website, ${ }^{30}$ a blog, ${ }^{31}$ a Facebook account, ${ }^{32}$ and a newsletter (called Templo Zuihoji), as well as the appearance of Roshi Oshiro and other members of the core group in the public media. ${ }^{33}$ Despite these efforts, Soto Zen Buddhism has not yet gained a positive image in Peruvian culture at large, as it has in Brazil ${ }^{34}$, but remains a little known phenomenon except for practitioners, religiously curious people, and some intellectuals.

In spite of this intense missionary work, not all members of the Soto Zen community share the same aim and objectives in this effort. Certainly, there is an underlying traditional understanding of the spread of the Dharma: the notion of a specific buddha-mind, preserved by a spiritual elite of masters and disciples through centuries, founded in China by an Indian monk called Bodhidharma. To its adherents the buddha-mind is neither a doctrine nor the result of human work, but the enlightened consciousness of Sakyamuni Buddha itself, passed along through generations. ${ }^{35}$ The aim of any missionary work is to provide the means to different people to awaken to reality. In the words of one commentator: "The underlying principle here is that the mind by its own nature is pure, indeed it is none other than the enlightened awareness of a Buddha. So the mediator's chief task is to 'get out of the way,' so that this innate Buddha-mind can manifest". ${ }^{36}$ There is a confluence in the

\footnotetext{
${ }^{30}$ http://www.sotozenperu.net/ (accessed 10 October 2016).

${ }^{31}$ http://comunidadzensotoshu.blogspot.ca/ (accessed 10 October 2016).

${ }^{32}$ https://www.facebook.com/ComunidadZenSotoshu (accessed 10 October 2016).

${ }^{33}$ La Mula Reportajes, El Zen. Entrevista a Jisen Oshiro.

${ }^{34}$ C. Rocha, Zen in Brazil.

${ }^{35}$ T.G. Foulk, The spread of Chan (Zen) Buddhism, pp. 453-454.

${ }^{36}$ B.A. Wallace, The Spectrum of Buddhist Practice in the West, p. 40.
} 
responses of the interviewees to the fact that Soto Zen does not proselytize but rather, it responds to persons who manifest interest.

However, as mentioned above, some members see the missionary effort to be sought mainly through the practice of meditation, keeping Soto Zen rituals in a secondary place, while others (first and foremost Roshi Oshiro and Novice Castilla) want to underscore the importance of both zazen and liturgy. As we will see, this makes room for inner tensions based on the way practice is understood.

In the light of what has been said, it is possible to affirm that the Soto Zen community has being successful in building a religious subculture. They constitute a religious group which distinguishes itself from the broader society without completely separating from it. What unites them is a desire to keep with an internal orthodoxy and the fact that they share a meaningful understanding of the world and of their moral purpose within it. Members who choose to become part of the group (instead of inheriting membership) receive from it a strong sense of belonging. ${ }^{37}$ The following analysis will provide more insight into the strengths and weaknesses of this particular religious subculture.

\section{Confrontation and Conflict}

The confrontation and conflict mode describes, on one hand, the processes by which a foreign religion presents its particularities in contrast to existing religions (pointing out the deficiencies of the latter or the appropriateness of the new tradition). On the other hand, it also expresses the degree to which the host culture rejects or accepts the new religious tradition.

\section{Advantages and Criticisms}

In this regard, Soto Zen members in Peru highlighted the fact that in the new religious tradition there was no notion of guilt as in Christianity, nor the figure of an "anthropomorphized God." Others have added the negative effects of a notion of punishment. Yet others also pointed to the fact that there is a concern for the "after life," which alienates people from the present. Among doctrinal reasons for Soto Zen superiority over the predominant Christian religious milieu in Peru, there were also mentioned the constant questioning of things and what they perceive as its "lack of dogma.”

The perceived shortcomings of Catholicism in Peru also give space for the rise of new religious movements (at least "new" in the Peruvian context), Soto Zen among

${ }^{37}$ C. Smith, American Evangelicalism. 
them. Paul, a Japanese-Peruvian, mentions the fact that in his family "in the same way we carried on Buddhist rites and customs, we were also baptized as Catholics; because of this our knowledge about these issues is a mix of either source without good explanations."38 Many other respondents characterize their past experience with Christianity as distinct from their spirituality; from their own efforts to get more deeply in touch with themselves. They also characterized Christianity as centered too much on external rituals and in the use of reason.

For her part, Roshi Oshiro has publicly explained how in Soto Zen there are no differences between men and women in regards to becoming monks and assuming an official role of religious leadership ${ }^{39}$. This seems to be aimed at bringing up an intentional contrast with Catholic Christianity, where the priesthood is strictly reserved for men. To this it should be added that she underscored the stress on living a good life "here and now" as something proper to Soto Zen and, by contrast, superior than Christian eschatology which, in her view, impels Christians to live a good life for something that comes after this world ${ }^{40}$.

\section{Host Culture and Religious Market}

On the side of the host culture, it should be said that the contemporary Peruvian setting constitutes a positive environment for Soto Zen. The Peruvian Constitution of 1979 disestablished the Catholic Church as the official religion, a position that was maintained in the current Constitution of 1983. As a consequence, Soto Zen Buddhists receive, legally, the same treatment on the part of the State as any other religion. In the last 15 years, on the other hand, the country, especially in the urban areas, has experienced a steady period of economic growth, the widening of the middle-class and the reduction of the level of poverty ${ }^{41}$. Additionally, there have been significant improvements to basic public services. This has also benefited the Soto Zen community, particularly because at present its more committed practitioners are people very much interested in zazen, something one usually can only aspire to practice after having taken care of one's basic living needs. In general, respondents did not report problems with the host culture as such but in a few specific interpersonal situations.

\footnotetext{
${ }^{38}$ Paul, personal communication, 11 September 2013.

${ }^{39}$ La Mula Reportajes, El Zen. Entrevista a Jisen Oshiro; J. Oshiro Zen Sotoshu, p. 17. For a critical assessment of this view see R. Gross, Buddhism after Patriarchy, S. Covell, Japanese Temple Buddhism and P. Arai, Women Living Zen.

${ }^{40}$ El Zen. Entrevista a Jisen Oshiro

${ }^{41}$ F. Jaramillo; O. Zambrano, Nota técnica: La clase media en el Peru.
} 
The competitive religious market in Peru is composed of a wide number of religious organizations competing for adherents. Table 2 shows the more important groupings of them and the ways in which religious membership has evolved between 1972 and 2007, which is the last year of which official census figures exist.

Table 2: Religious Membership in Peru (\% of Total Population)

\begin{tabular}{|c|c|c|c|c|}
\hline Religious Groups & Census & 1993 & 2007 \\
\hline Catholics & 1972 & 1981 & 89 & 81.3 \\
\hline Evangelical Christians & 96.4 & 94.6 & 6.8 & 12.5 \\
\hline Other Religions & 2.5 & 5 & 2.8 & 3.3 \\
\hline Without Religion & 0.7 & 0.2 & 1.4 & 2.9 \\
\hline Total & 0.4 & 0.2 & 100 & 100 \\
\hline Population (Millions) & 100 & 100 & 22 & 28 \\
\hline \multicolumn{5}{|l}{ Sources: Marzal 2000; Instituto Nacional de Estadística e Informática (2008) } \\
\hline
\end{tabular}

These religious organizations can be located within a continuum that ranges from groups in very low tension with the host culture - mostly characterized as a kind of popular syncretistic Catholicism - to those in moderate tension, up to those in a high tension mode. Soto Zen should be placed among the latter, mainly competing with other Buddhist groups, Christian Evangelical groups, and with "revivalist" movements within the Catholic Church, which appeared in the wake of the Second Vatican Council (Charismatic Renewal in the Spirit, John XXIII Retreats, Christian Life Movement, etc.). They all share in common their distinctiveness, separation and antagonism in regards to the socio-cultural milieu ${ }^{42}$.

However, according to Stark and Finke's theory ${ }^{43}$, religious groups in higher tension only thrive if they are able to complement their high demands on practitioners with higher value of the spiritual good offered. Within this context, one would expect Soto Zen leaders in Peru balancing both factors in order for the community to grow. It would be expected that members without a Japanese background and a greater interest in meditation, would be encouraged to do so while finding other aspects of the practice meaningful (as, for example, through translations of sutras into Spanish). Conversely, Japanese-Peruvian members should be introduced to ritual practices, and also to meditation. in ways that may help them recognize their value (again through translations and other means) and, thus, strengthen their commitment. Soto Zen leaders would take advantage of the fact that their tradition is, in a broad sense, already part of the religious capital of this group, which in principle makes many of them prone to embrace Soto Zen before considering, say, Evangelical Christianity. If these strategies

\footnotetext{
${ }^{42}$ M. Marzal, Categorías y números en la religión del Perú hoy.

${ }^{43}$ R. Stark; R. Finke, Acts of Faith, pp. 141-154
} 
are put into place, the scenario could be one in which the higher commitment fosters growth which, in turn strengthens the latter. Otherwise, the scenario could be one of a group that does not grow and stalls ${ }^{44}$.

Our findings so far show how it is difficult for Soto Zen leaders to deal with the different main interests of the members of the community and even to harmonize those with their own. The fact that the core group is comprised of people with a clear focus on meditation makes things more complicated for them. The following sections will throw more light on the causes of this phenomenon.

\section{Ambiguity and Adaptation}

This mode analyzes how the specific socio-cultural contexts belonging to both the foreign religion and the host culture bring up ambiguities. These may be "unavoidable" or "intentional." In the first case, ambiguities are those that normally arise due to the very different framework of key concepts through which reality is seen, and may entail the adoption of some forms that belong to the "already established" religions. In the second case, certain adaptations to the host culture, usually driven by the missionary impetus of the new foreign religion, are willingly done in order to appear less "unfamiliar" and to avoid excessive tensions and conflicts.

\section{Unavoidable and Intentional Ambiguities}

The most common unavoidable ambiguities are those related to the use of Catholic concepts to refer to Soto Zen principles and practices. Some celebrations coincide with Catholic annual feasts, as in the case of the celebration of the Buddha's enlightenment on December $8^{\text {th }}$. This coincides with the Feast of the Immaculate Conception (which in Peru is a civic holiday).

Among intentional ambiguities it is worth mentioning the performance of rites for newborn children and for marriages can be counted as relying on intentional ambiguity. These are not part of the more traditional Zen tradition, but, on the other hand, they had already been assumed by Soto Zen in Japan and resemble the Christian rites of Baptism and Marriage. All respondents consistently reject any explicit intention of adapting Soto Zen to the predominantly Christian culture in Peru in order to attract potential practitioners. They explicitly say they do not make parallels between the Catholic/Christian calendar of celebrations and that of Soto Zen, nor relate Soto Zen doctrine to that of Catholic/Christian origin, nor assume ways of organization from the latter.

${ }^{44}$ Ibid., pp. 207-208 


\section{Uncertain Ambiguities}

There are some cases for which ambiguity is difficult to qualify. First, there is the use Roshi Oshiro makes of Spanish translations of works by Catholic priests who have been in Japan practicing Zen. Her experience of ten years living in Japan in a Soto monastery for foreigners, which delivered retreats for international Zen practitioners, the above-mentioned priests included, has proven very valuable in this regard. This makes sense from the standpoint of Soto Zen, since the school sees all religious traditions as expressions of the same Buddhahood. In this logic, to affirm that one could be Buddhist and Christian at the same time is unproblematic ${ }^{45}$. However, from the perspective of Christianity (Catholic and Evangelical) this is not so, since in this tradition a notion of a gradual historical revelation that finds it apex in Jesus Christ is of paramount importance, as is the universal and unique redemptive work carried out on the $\operatorname{cross}^{46}$. My research did not yield further information as to affirm if this situation is intentional or not, even taking into account that Roshi Oshiro is conversant in the Catholic tradition due to her family roots and school education.

Secondly, the fact that the Nambeizan Zuihoji Temple, from the outside, appears to be merely another house in the neighborhood where it is located should also be situated in a somewhat middle place between the two previously-mentioned types of ambiguities. There is no sign outside the facility to indicate its nature as a sacred place, perhaps to avoid possible tensions with neighbors or appearing too peculiar, or maybe because the same place is used as a dwelling by members of the "core group."

\section{Internal Conflicts on Adaptation}

Adaptations to the host culture seem to be problematic for Soto Zen in Peru. Their universe of symbols, sutras, internal organization, practices and lifestyle seem to be very much Japanese-like. This would not necessarily be a problem if there was a constant search to acculturate certain religious forms into the host culture, but for several respondents what has occurred so far is not enough. At present, there have been a number of accommodations, one of the most notable of which has been the translation of some sutras into Spanish to help with resources for more meaningful chanting. One

\footnotetext{
${ }^{45}$ Peru Shimpo, Rescatar of valores de nuestra tradición y respetar a los mayores.

${ }^{46}$ Congregation for the Doctrine of Faith, Declaration on the Unicity and Salvific Universality of Jesus Christ and the Church.
} 
core group member said that Soto Zen "should adapt to its context," 47 while another affirmed that it should keep faithful to Japanese Soto Zen ways "but with flexibility." 48

Another interviewee, Pedro, goes farther in his comments: the community "should remain faithful to Soto Zen in Japan in what is referred to its teachings but not its practices. We are in Peru and in the twenty-first century, not in Japan in the thirteenth century. There are several kinds of differences and Sotoshu is resistant to taking them into account. I would like that while we celebrate the $110^{\text {th }}$ anniversary some would take advantage and promote a Zen more adapted to South America, although I do not know how this should be ... The Master [Roshi Oshiro] wants us to learn [the sutras] by memory and in a very ancient Japanese nobody understands and that is very difficult to memorize. I would like to study the sutras in Spanish, but that is hardly done." 49

\section{Soto Zen Reorientation}

The re-orientation mode takes place by way of a critical examination of the ambiguities that may have risen. The criteria for this discernment belongs to the religious tradition as it is lived in its "country of origin". There is a search for a reduction of ambiguities and for an increased faithfulness to the "genuine tradition." The amount of tension this may entail is directly related to the ease with which the so-called "new religion" accepts changes or not. The "new religion" profile is sharpened and stressed. This mode may reflect the logic of "revivalist movements" within a specific religious tradition.

Soto Zen leaders in Peru have clearly decided to carry out some reorientation strategies as defined above. The first one has to do with the recitation of the sutras. Around 2009, Roshi Oshiro tried to use English and Italian translations that had been developed for other places in order to make the practice of chanting more meaningful for practitioners. After some time, however, she returned to the Japanese, since, in her own words, "it sounded very different." ${ }^{50}$ However, this has been balanced with the translation into Spanish of sutras for meditation and ceremonies, which have been published in order to provide the meaning of the chants, which are done in Japanese. In spite of this fact, core group members are still dissatisfied with the adaptation experiences. It also seems that the assessment of Soto Zen leaders in Peru on this matter has been, in general, to go back to the tradition of Japanese Soto Zen.

\footnotetext{
${ }^{47}$ Mario, personal communication, 16 September 2013.

${ }^{48}$ Roberto, personal communication, 21 September 2013.

${ }^{49}$ Pedro, personal communication, 15 September 2013.

${ }^{50}$ Jisen Oshiro, personal communication, 25 February 2009.
} 
The second issue is related to the phenomenon of dual affiliations: the case of practitioners who see themselves as Catholic and Soto Zen at the same time. In order to diminish ambiguity, there is a process through which the practitioner who desires a closer involvement in the life of the Soto Zen community in Peru ends up putting aside other (usually Christian) convictions related to human fulfillment in order to focus exclusively on the Soto Zen teachings, practices and ethical standards. Since this approach is freely made, it seems natural. Nevertheless, it seems the standards for a closer practice of Soto Zen are clearly established, which may be seen as focusing on the best way for acquiring Buddhahood rather than trying the means offered by other religious traditions. As Carlos put it, he would not keep both religious traditions, Christianity and Zen, "because they are two completely different worldviews, and it would cause the practitioner a great deal of confusion to keep them both." ${ }^{51}$. Other respondents have similarly pointed out the strong difference between what they see to be "Christian rationalism" and the Soto Zen approach, for which reason could be a hindrance for enlightenment, therefore being something to overcome. In connection with this, the fact that some of the members of the core group have assumed Dharma names seems to be a sign of a strong change in the way they construct their self-identities (for example, Sengen for Néstor, Tenkai for Diego, or Anji for Beatriz).

Another indication of this re-orientation of the practice of Zen is the fact that, for Sengen Castilla, one of the disciples of Roshi Oshiro who has been ordained as a Soto Zen novice, the goal is to focus, for the time being, on establishing Soto Zen in a way most faithful to the way it is lived in Japan. In his view, this will mean that the rest of the informal sangha would be encouraged to reorient themselves in a similar manner. "We have a historical and cultural basis. In Peru practice started by Japanese influence and it has remained that way. The formation of the Peruvian novices is also inspired in the Japanese tradition. If some day it takes its own essence, it would be for motives different than those operative in the United States and Europe." ${ }^{2}$ The other novice, Tankai Sanchez, concurs: "I think it is better for Sotoshu in Peru to be faithful to the ways of Soto Zen in Japan in order to get started. Once the practice is assimilated in our context, it will develop its own ways." 53 This means that the current stress on reorientation could be put aside sometime in the future. However, the criteria for evaluating when that time would have arrived were not clearly explained by the Soto Zen leaders. It seems that some uncertainty is also shared by Soto Zen international leaders. In connection with this Pedro reports that when he spoke with the Japanese monks who came from Japan for the celebration of Soto Zen in South America, she

\footnotetext{
${ }^{51}$ Carlos, personal communication, 27 September 2013.

52 Sengen Castilla, personal communication, 13 September 2013.

53 Tenkai Sanchez, personal communication, 22 September 2013.
} 
perceived that "they were reluctant towards any Westernization of Zen [...] I know that the Japanese [monks] do not want that influence to occur. I believe that, for Japanese [monks], the fact that Zen had expanded beyond their country's boundaries is a true problem." 54 There is even the perception that the response by Soto Zen's headquarters to the demands for adaptation has been strengthening control over the groups of practitioners in South America. ${ }^{55}$

As a consequence of what has been said, the Soto Zen community in Peru has not entered into the mode of innovative self-development.

\section{Assessing Soto Zen's Tensions}

In Peru, Soto Zen is neither a marker of modernization nor do its practitioners enjoy any higher social status for being so. It is rather a spiritual option for some people who carry on a personal quest or see it as part of their heritage within a majority who inhabit a syncretistic Catholic religious world in which, in spite of secularizing trends, they tend to be comfortable. This is in contrast to the Brazilian case, in which "being Zen" meant to be modern, and where religious exploration is much more frequent ${ }^{56}$. The Peruvian project of modernizing the country, both at the level of society and culture, do not include Zen Buddhism in any sense.

As a consequence, tensions regarding adaptation cannot necessarily be characterized as occurring between "traditionalist" authorities and "modernizing" lay members. The latter, in spite of their criticisms and the fact that many of them know about Zen groups in North America, influenced by D.T. Suzuki and the Kyoto School, do recognize and respect the Japanese cultural roots of the tradition. They are not simply willing to "Westernize" it. It is precisely because of this that it is difficult for them to articulate the kind of adaptations they want in Peru.

On the side of Soto Zen's ordained leadership, translation of sutras into the vernacular for both liturgies and meditation seems to have become the most contentious issue. There is a clear concern for not skewing the spiritual progress of practitioners by exposing them to translations unfaithful to the original texts in Chinese or Japanese. However, they do acknowledge the need for adaptation and particularly for translating the sutras into the vernacular, and texts that would make ceremonies, mediation and community life more meaningful. Nonetheless, it is not clear why they have not acted faster, considering that a number of official English translations have been produced since 1996 by the "Soto Zen Text Project," promoted by the

\footnotetext{
${ }^{54}$ Pedro, personal communication, 15 September 2013.

${ }_{55}$ Pedro, personal communication, 10 September 2013.

${ }^{56}$ C. Rocha, Zen in Brazil.
} 
headquarters in Japan. ${ }^{57}$ They could have used them as such, since a majority of core group members are bilingual, or as a reference for Spanish translations beyond the ones they have just published. Besides this, it is also unclear what their rationale is for considering what makes an adaptation appropriate, and for their decision to minimize acculturation until the Japanese form of Soto Zen takes roots. Unfortunately, at this point my research does not provide answers to these questions.

Finally, other reported tensions are related to Zen practices. They consist of different views about how to live/prioritize meditation and liturgy. The ordained leaders want to balance both, whereas Japanese-Peruvians just the latter, and the rest of practitioners want to meditate while keeping ceremonies in a secondary place. In this regard, the ordained leaders seem to hope that getting deeper into tradition's principles and worldview would diminish them in both mentioned groups. This could be the case since members of the core group are very open to learning, and some JapanesePeruvians seem to be willing to get into the practice beyond traditional liturgies.

\section{Conclusions}

My research has lead me to conclude that the Soto Zen Buddhist presence in Peru can be best characterized by the processive modes of conflict and confrontation, ambiguity, and, particularly, re-orientation. It has already established a core group and a broader group of practitioners, and put into place a variety of means of contact aimed at two well delimited audiences: that of Japanese-Peruvians and that of the public at large. It has also deployed important organizational, institutional, communicational and financial resources for is missionary efforts. Moreover, it has strategically positioned itself to effectively communicate with both audiences. With regards to JapanesePeruvian community, Soto Zen Buddhism has established institutional alliances with Japanese-Peruvian, organizations through the formation of a discourse focused on the preservation of cultural identity through the use of Soto Zen practices and as a starting point for further cultural exploration. With regards to the general public, a new temple has been set up in Lima which is geographically close to the homes of core group members, as well as a large educated urban population. In general, Soto Zen Buddhism has established a subculture in which practitioners show a clear commitment to competing in the religious market, while collaboration with other groups (Buddhist or other) is not stressed.

Secondly, within the Peruvian religious market place Soto Zen has its best chances of growth if it locates itself in high tension with the sociocultural milieu, mainly in

\footnotetext{
${ }^{57}$ Some translations are available online here: http://web.stanford.edu/group/scbs/sztp3/ (accessed 10 October 2016).
} 
competition with other Buddhist groups, Evangelical Christianity and Catholic revivalist movements. Among its strengths there is its appeal to people who are looking for significant spiritual experiences, as well as Soto Zen organization and resources. A weak point is that it requires a costly investment in acquiring a new religious capital the exception being for Japanese-Peruvians who already are close to it due to their family heritage. However, if its costs are too high and are not balanced with perceived religious value (as through zazen, for example) the group may stall and probably decay. This means that the adaptations and translations of Soto Zen practices - such as sutras or meditative chanting - which may lessen the cost of entrance are of paramount importance.

Thirdly, even though the dominant focus of Soto Zen practitioners has been that of nurturing their own practice and reaching out to new practitioners, a lot of time and energy has been put on working out cultural adaptation and re-orientation back towards Japanese-based practice. At the present time there is clearly an option for the latter, which in turn causes strong inner tensions between the ordained leaders on the one hand, and the rest of core group members on the other. Such tensions exist around both the goals of Soto Zen practice and acculturation. They become more complicated for Soto Zen leaders since the core group is the basis for its growth in the country, and has already proved it can live on its own. Additionally, tensions surrounding acculturation have built over time and have not been worked through. Within this context, the strategy of both international and Peruvian leadership has maintained a mode of constant re-orientation which will persist until a certain level of maturity develops in Soto Zen Practice. However, this has not overcome the above mentioned tensions, and has led to the alienation of some practitioners. It has also led to the creation of groups solely aimed at meditation, or to the migration of some members to other Buddhist groups. Future research should focus on understanding the causes of this resistance to adaptation. 


\section{Bibliographical References}

Arai, Paula: Women Living Zen: Japanese Soto Buddhist Nuns. Oxford: Oxford University Press, 2012.

Baumann, Martin: The transplantation of Buddhism to Germany: Processive modes and strategies of adaptation. Method \& Theory in the Study of Religion, 6(1), 1994, pp. $38-50$.

Barrett, David B., George T. Kurian and Todd M. Johnson: World Christian Encyclopedia. A Comparative Survey of Churches and Religions in the Modern World. Vol. I. Oxford: Oxford University Press, 2001.

Carini, Catón Eduardo: Budismo global, budismo local: Uma recorrida por los grupos Zen argentinos. REVER 3, 2005: pp.178-195.

Carini, Catón Eduardo: Ritual y poder en los centros budistas zen argentinos. Horizonte 6 (11), 2007, pp. 71-87.

Carini, Catón Eduardo: Las nuevas tierras de Buda: Globalización, medios de comunicación y descentralización en una minoría religiosa de la Argentina. Debates do NER 10 (16). 2009, pp. 49-70.

Castilla, Nestor, 2004. "Grupo Amigos del Budismo Zen in Lima, Peru." Dharma Eye. News of Soto Zen Buddhism: Teachings and Practice (August 2004), p. 14. http://www.sotozen-net.or.jp/kokusai/journal/de14/de14 02.htm (accessed 2 November 2008).

Comunidad Zen Sotoshu, n.d. http://sotozenperu.net/ (accessed 30 July 2013).

Congregation for the Doctrine of Faith, 2000. Declaration on the Unicity and Salvific Universality of Jesus Christ and the Church.

http://www.vatican.va/roman curia/congregations/cfaith/documents/rc con cfaith d oc 20000806 dominus-iesus en.html (accessed 21 July 2015).

Covell, Stephen: Japanese Temple Buddhism: Worldliness in a Religion of Renunciation. Honolulu: University of Hawai'i Press, 2006. 
El Comercio "El templo Zen mas antiguo de Sudamerica esta en Cañete." 11.8.2007. http://elcomercio.pe/peru/lima/templo-zen-mas-antiguo-sudamerica-esta-canete 1noticia-1616133 (accessed 2 September 2013).

Foulk, T. G: The spread of Chan (Zen) Buddhism. In: Heirman, Ann: Bumbacher, Stephan (eds.): The spread of Buddhism. Leiden, Boston: Brill, 2007, pp. 433-456.

Fukumoto, Mary: Hacia un nuevo sol. Japoneses y sus descendientes en el Perú. Historia, cultura e identidad. Lima: Asociación Peruano Japonesa del Perú, 1997.

García, Zully: "Sesshin in Peru." Dharma Eye. News of Soto Zen Buddhism: Teachings and Practice (February 2005), p. 15. http://www.sotozen-net.or.jp/kokusai /journal/de15/de15 03.htm (accessed 24 November 2008).

Gross, Rita: Buddhism after Patriarchy. New York: State of New York Press, 1992.

Instituto Nacional de Estadística e Informática - INEI: Perfil sociodemográfico del Perú. Lima: Dirección Técnica de Demografía y Estudios Sociales, Centro de Investigación y Desarrollo del INEI, 2008.

Jaramillo, Fidel and Omar Zambrano: Nota técnica: La clase media en el Peru. Cuantificacion y evolución reciente. Washington, D.C.: Banco Interamericano de Desarrollo. http://www.lampadia.com/archivos/BID la-clase-media-en-peru.pdf (accessed 30 October 2013).

La Mula Reportajes: “El Zen. Entrevista a Jisen Oshiro.” http://www.youtube.com / watch?v=8buoaudagVc\&list=PLhxo8I138BX9tOtT0e5uS1fSgu Dy--Vr\&index=1 (accessed 29 October 2013).

Lausent-Herrera, Isabelle: Pasado y presente de la comunidad japonesa en el Perú. Lima: IFEA, IEP Ediciones, 1991.

Marzal, Manuel: Categorías y números en la religión del Perú hoy. In Marzal, Manuel; Romero, Catalina, Sánchez Paredes, José (eds.): La religión en el Perú al filo del milenio. Lima: Pontificia Universidad Católica, 2000, pp. 21-55.

Miyoshi, Koichi: "One Hundred Years of Teaching Activity in South America." Dharma Eye. News of Soto Zen Buddhism: Teachings and Practice (August 2004), p. 14. 
http://www.sotozen-net.or.jp/kokusai/journal/de14/de14 01.htm (accessed

November 2008).

Morimoto, Amelia: La religión entre los Nikkei del Perú, n.d. http://www.discovernikkei.org/forum/en/node/1647 (accessed 20 October 2008)

Morimoto, Amelia: Los Japoneses y sus descendientes en el Perú. Lima: Fondo Editorial del Congreso del Perú, 1999.

Oshiro, Jisen (ed.): Zen Sotoshu: 110 Años en América del Sur. Lima: Comunidad Budista Sotoshu, 2013.

Peru Shimpo: "Rescatar of valores de nuestra tradición y respetar a los mayores." 18.4.2012. http://www.perushimpo.com/noticias.php?idp=1731 (accessed 21 July 2015).

Peru Shimpo: "Templo Jionji fue el sosten espiritual para los inmigrantes japoneses." 27.8.2013. http://www.perushimpo.com/noticias.php?idp=4428 (accessed 21 July 2015).

Rocha, Cristina: Zen Buddhism in Brazil: Japanese or Brazilian?, Journal of Global Buddhism, 1, 2000, pp. 31-55.

Rocha, Cristina: Being a Zen Buddhist Brazilian: Juggling Multiple Religious Identities in the Land of Catholicism. In: Learman, Linda (ed.): Buddhist Missionaries in the Era of Globalization. Hawai'i: University of Hawai'i Press, 2005, pp. 140-161.

Rocha, Cristina: Zen in Brazil. Honolulu: University of Hawai'i Press, 2006.

Smith, Christian: American Evangelicalism: Embattled and Thriving. Chicago: University of Chicago Press, 1998.

Stark, Rodney and Roger Finke: Acts of Faith. Explaining the Human Side of Religion. Berkeley: University of California Press, 2000.

Tokeshi, Juan; Fukumoto, Mary: Integración de los Nikkei a la nacionalidad peruana: 87 años después. In: Kapsoli, Wilfredo (ed.), Primer Seminario sobre Poblaciones 
Inmigrantes. Actas. Lima, 9 y 10 de mayo de 1986. Lima: Consejo Nacional de Ciencia y Tecnología, 1988, pp. 253-271.

Usarski, Frank: Buddhism in Brazil and Its Impact on the Larger Brazilian Society. In: Prebish, Charles; Baumann, Martin (eds.): Westward Dharma. Buddhism Beyond Asia. Berkeley: University of California Press, 2002, pp. 163-176.

Usarski, Frank: Buddhism in South America. An Overview with Reference to the South American Context." In: Abeynayake, Oliver; Tilakaratne, Asanga (eds.) 2600 Years of Sambuddhatva: Global Journey of Awakening. Sri Lanka: Ministry of Buddhasasana and Religious Affairs, 2011, pp 527-540.

Wallace, B.Alan: The Spectrum of Buddhist Practice in the West. In: In: Prebish, Charles; Baumann, Martin (eds.): Westward Dharma. Buddhism Beyond Asia. Berkeley: University of California Press, 2002, pp. 34-50.

Recebido: 10/10/2016

Aprovado: 17/11/2016 